\title{
ASSESSMENT SCALE FOR BEHAVIOUR IN BULFIGHTING CATTLE (EBL 10). RELIABILITY AND VALIDITY STUDIES
}

\author{
ESCALA DE EVALUACIÓN DEL COMPORTAMIENTO EN BOVINOS DE LIDIA (EBL-10). \\ ESTUDIOS DEFIABILIDADY VALIDACIÓN
}

\author{
Almenara-Barrios, J. ${ }^{1}$ and García González-Gordon, R. ${ }^{2 *}$
}

${ }^{1}$ Área de Medicina Preventiva y Salud Pública (Bioestadística). Universidad de Cádiz. Edificio Ciencias de la Salud. Avda. Ana de Viya, № 52.11009 Cádiz. España. jose.almenara@uca.es ${ }^{2}$ Departamento de Psicología. Universidad de Cádiz. Campus Universitario Río San Pedro s/n. 11510 Puerto Real. Cádiz. España. *rodrigo.garcia@uca.es

\section{AdDitiOnAL KEYWORDS}

Bos taurus.

\section{SUMMARY}

Our intention is to objectively assess the behavior patterns related to bravery in bullfighting cattle by means of a scale devised for this purpose. Reliability and validity studies have been carried out. This instrument will allow researchers to analyse inherited behaviour characters, permitting breeders to select in a more objective and systematic way. The evaluation scale of bravery in Fighting bovines, EBL 10, has been constructed. A glossary has also been developed with the distinguishing definitions of the ten dimensions dealt with, as well as a set of objective indicators for each dimension. A feasibility and validity study of the scale has been undertaken, assessing a sample made up of 380 bulls' behavior during a bullfight. Previously, a reliability study was carried out by two evaluators in a sample of 116 cows during a practical bravery test, (tienta). The scale (EBL 10) is a valid and reliable tool for standard behavior assessment related to bravery in fighting bovines and may be useful for both researchers and breeders alike.

\section{RESUMEN}

Se pretende evaluar objetivamente los comportamientos relacionados con la bravura en bovinos de Lidia mediante una escala elaborada con dicho propósito. Se realizaron los estudios de fiabilidad y viabilidad. Este instrumento permitirá a los investigadores estudiar la heredabilidad de

Recibido: 23-2-09. Aceptado: 22-7-09.

\section{Palabras clave adicionales}

Bos taurus.

caracteres comportamentales, posibilitando una selección ganadera más objetiva y sistemática. Se construyó la escala de evaluación de la bravura para bovinos de Lidia (EBL-10). Se desarrolló un glosario con las definiciones diferenciales de las diez dimensiones manejadas así como un conjunto de indicadores objetivos para cada dimensión. Se realizó un estudio de validación de la escala aplicándola a una muestra constituida por 380 toros durante la lidia. Previamente, se realizó un estudio de fiabilidad inter-evaluadores en una muestra de 116 hembras durante la tienta. Se dispone de un instrumento viable y fiable para medir el comportamiento relacionado con la bravura en bovinos de lidia, que puede ser útil a investigadores y ganaderos.

\section{INTRODUCTION}

Very few scientific studies exist about the behavior of fighting bulls (Vallejo et al., 2001) and genetic parameters of behaviour (Silva et al., 2006). The majority of which refer to the domesticated breeds of Bos taurus (Aguilar, 1991). The Fighting Bull is not a very extensive breed, found solely in some European countries and various in Latin America. However its greatest cultural impact is mainly in Spain, (taurine themes have been very common in painting, 


\section{ALMENARA-BARRIOSY GARCÍA GONZÁLEZ-GORDON}

sculpture and literature for various centuries), where it assumes a genetic heritage of inestimable value.

Also, in Spain, the bull represents an important economic contribution to the country. The taurine world makes up $2 \%$ of the G.N.P. From an economic view point, this farming sector contributes between $35 \%$ and $40 \%$ of the total agrarian production in Spain (Domínguez, 2005). There are more than one thousand ranches belonging to five organisations. The Union of Fighting Bull Breeders (Unión de Criadores de Toros de Lidia-UCTL), is one of these associations and if we add up the extent of the lands on which the cattle graze among the ranches associated with the UCTL, there are more than 300 thousand hectares, an expanse of land greater than some Spanish counties, such as Guipuzcoa.

In Spain, the fighting bull has been selectively bred for more than two centuries and if this selection takes into account aspects related to the phenotype, they are above all, the character behaviours which prevail in a definitive way. The traditional system that breeders use to evaluate and record the behaviour of cows during bravery testing (tienta), and bulls during a bullfight has a series of limitations, (García et al., 2002, 2003), which has led us to design a standard scale for the evaluation of bravery in fighting bovines, (EBL 10) (García and Almenara, 2004, 2005). This scale has been subjected to strict quality criteria which are currently used in Psychometrics and Biostatistics and constitute a key instrument within the Programme for Genetic Improvement, Selectivity and Conservation which The Union of Fighting Bull Breeders (UCTL) has recently presented to the Ministry of Agriculture(UCTL, 2006).

Once these quality criteria have been completed, this scale could permit breeders to carry out a more objective and systematic selection process, while at the same time providing researchers with cuantative and reliable information on which they could base their studies about the inheritance of behavior characteristics. Likewise, this scale could serve to objectively evaluate the quality of bulls fought at specific taurine festivals, providing cuantative scores for comparison between preceding and successive years. Finally, this scale can also be useful to foster and spread interest in the taurine world, helping beginners to better understand such complex and fascinating behavior such as that of bravery in Fighting Bulls.

Essentially, we think that bravery in the fighting bovine is a hypothetical concept which appears inside the definition of a complex phenomenon where a group of 'variables or dimensions interact and are, at times, difficult to define. On evaluating a phenomenon of the aforesaid characteristics it is important therefore to place ourselves inside a dimensional model which delimits, in the first place, the number of variables or dimensions that it can consist of. When a phenomenon is complex it is seen as a multidimensional framework, where basic dimensions should be delimited concerning those the evaluation is centered on, since their actual number is practically inaccessible (Salvador et al., 2000).

By developing this line of argument science has been able to figure out the dimensional components of intelligence, pain, and other entities of interest for Psychology and Medicine. And now, we intend to carry out a task from the same scientific perspective but with a view to understanding and knowing the behavioral characteristics of this unique animal; the fighting bull. We have begun our programme, as stated above, with the elaboration of a standardized scale for the evaluation of bravery in fighting bovines (EBL 10). The final aim of the current work is to present the structure of the aforementioned multidimensional scale for the evaluation of bravery in fighting bovines, and its subsequent validation. 


\section{MATERIAL AND METHODS}

The first part of the study was carried out using a sample made up of 116 fighting cows (from M.P. García Fdez-Palacios livestock) during the process of tientas, or practical bravery test. Te second part of the study was completed with a total of 380 bulls, of which 262 were fought in the Madrid bullring (Las Ventas) (Almenara and García, 2004), and 118 in the El Puerto de Santa Maria bullring.

For this, we have constructed a scale of ten dimensions, with opposite descriptors at each extreme of the measured dimension or item. In this way, the following characteristics are measured: 1) lack of mobility to mobility, 2) indecision to charging decisively, quickly and with impetus, 3 ) distraction to fixed attention, 4) charging at the mounted bullfighter's horse (picador) without style to charging with style, 5) charging at the cape without style to charging with style, 6) docility to fierceness, 7) cunningness to nobility, 8) weakness to strength, 9) lack of transmission of emotion to public to transmission, 10) decreasing fighting spirit to increasing fighting spirit.

A scale thus constructed allows us to characterize an animal with a single score which is the sum of all the scores obtained for each dimension.

The following example about the evaluation of the first of the ten dimensions of bravery, mobility, can be seen in the figure $\mathbf{1}$, and gives the reader a more graphic idea of how the scale works.

We have also developed a glossary of all the dimensions dealt with and a set of indicators to evaluate them.

Later, the scale was subjected to a reliability and validity study.

\section{RELIABILITY}

The reliability study between evaluators of the EBL 10 scale was carried out using a sample made up of 116 fighting cows (from M.P. García Fdez-Palacios livestock) during the process of tientas, or practical bravery test. The ten dimensions of the EBL 10 test were measured in all animals by two trained evaluators.

Each animal obtained a score in every item of the scale which ranged from 0 and 5 , representing a gradient where the highest score, (5), reflected the most positive expression of the animal's attitude. The addition of the scores obtained in each dimension of the scale gave us the final score for the animal, which ranged from 0 to 50 , thus allowing us to rank the animals in order and to compare them.

All the individual measurements given by both evaluators were used to calculate the intraclass correlation coefficient between scores by means of a mixed effects model. Also a categorical classification of the animal in brave or non - brave behaviour
1. LACK OF MOBILITY

Scarcity, clumsiness, heaviness

\section{MOBILITY}

Constant activity, galloping a set path, rhythm, agility and speed

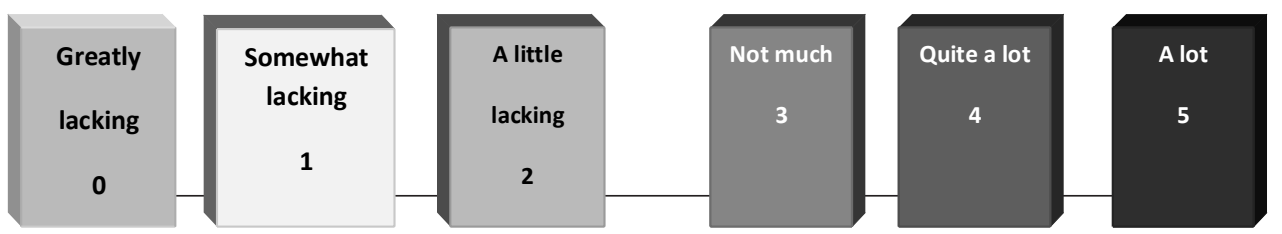

Figure 1. Evaluation of the first dimension: mobility. (Evaluación de la primera dimensión: movilidad). 


\section{ALMENARA-BARRIOSY GARCÍA GONZÁLEZ-GORDON}

was carried out. Here, the concordance was evaluated according to Kappa's coefficient.

\section{VALIDITY}

Subsequently, we used the same EBL 10 scale to carry out a validation study with a total of 380 bulls, of which 262 were fought in the Madrid bullring (Las Ventas), and 118 in the El Puerto de Santa Maria bullring.

We have calculated an important number of statistical indicators of which here, we have only presented the mean, the standard deviation, and the minimum and maximum values obtained. Later, the results obtained in both bullrings were compared with the aim of evaluating the possible existence of significant differences between the bulls fought in each bullring.

Finally, we performed a principal components analysis (PCA) with the matrix of initial data, given that the study of an intangible concept as is bravery in fighting bulls, requires a multivariant statistical analysis (Cuadras, 1996). Moreover, it will help to construct validity for the scale if we find one or more underlying variables which are not susceptible to being measured directly and which can be substituted by synthetic variables or components (Silva, 1997; Schuling et al., 1993).

Principal components analysis (PCA) is perhaps the oldest technique of multivariant analysis. It was first introduced by Pearson (1901), and developed independently by Hotelling (1933), to whom we owe its real development and applicability. As has happened with many other multivariant techniques, its practical applications will not be manifested until the neccessary computing techniques are developed (Jolliffe, 2002).

The central idea of PCA is to obtain a simplification of a group of data, generally quantitative, coming from the measurement of a group of interrelated variables. This aim is achieved by transforming to a new group of variables, the principal components (PC), which are uncorrelated, and which are ordered so that the first $\mathrm{PC}$ retain most of the variation present in all of the original variables (Jolliffe, 2002, and Almenara et al., 1998).

From a practical point of view, following González (1991), we can obtain the following objectives with this: 1) Synthesizing the information coming from an important volume of data. 2) Create indexes or new indicators, in our case bravery, represented by the CP. 3) Also, to use the technique as a prior step to others.

In the first place, the idea centres on resolving the problem of ranking, trying to ensure that all measurements carried out are included. For this, PCA can help us. As previously mentioned, it is able to originate a lineal combination of the original variables. With this, it can be obtained a specific score for every subject (fighting bovine), in every one of the chosen PCs, which enables us to put them in order. Also, these PCs can help us to figure out a specific model underlying (bravery) in the group of initial data, which are obtained by the process of interpreting the PCs.

The data will be treated statistically in the computer programmes SPSS (version 14) and Statgraphics Plus (version 5.1), both licensed by the University of Cádiz.

\section{RESULTS}

\section{RELIABILITY RESULTS}

The results obtained in the feasibility studies between evaluators indicate they are high. The intraclass correlation coefficient reached a value of $0.91(p=0.000)$ and the Kappa's coefficient was 0.76 ( $\mathrm{p}=$ 0.000).

\section{VALIDITYRESULTS}

We have divided the results of the validation study into: analysis of the variables studied, correlation of them, and creation of synthetic variables by means of PCA. 
Table I. Statistical descriptions of the ten dimensions of the EBL 10, for bulls fought in Madrid (San Isidro Festival) and El Puerto de Santa Maria (2004, 2005 and 2006). (Descripción estadística de las diez dimensiones de la EBL 10, en los toros lidiados en Madrid (Feria de San Isidro) y El Puerto de Santa María (2004, 2005 y 2006)).

\begin{tabular}{|c|c|c|c|c|c|}
\hline Dimensions & $\mathrm{n}$ & Mín. & Max. & Mean & SD \\
\hline Lack of mobility-mobility & 380 & 0 & 5 & 2.59 & 0.815 \\
\hline Indecision-decisive, quick to start charge & 380 & 0 & 5 & 2.41 & 0.853 \\
\hline Distraction-fixed attention & 380 & 0 & 5 & 2.69 & 0.767 \\
\hline Charging at picador's horse without style-with style & 379 & 0 & 5 & 1.91 & 0.821 \\
\hline Charging at lures without style-with style & 380 & 0 & 5 & 2.12 & 0.960 \\
\hline Docility-fierceness & 380 & 1 & 5 & 2.52 & 0.817 \\
\hline Cunningness-nobility & 380 & 1 & 5 & 2.78 & 0.879 \\
\hline Weakness-strength & 380 & 0 & 5 & 2.51 & 0.962 \\
\hline Lack of transmission to public-transmission & 380 & 0 & 5 & 2.09 & 1.086 \\
\hline Decreasing fighting spirit-increasing fighting spirit & 380 & 0 & 5 & 1.84 & 1.040 \\
\hline
\end{tabular}

\section{Analysis of studied variables}

The mean, standard deviation (SD), the minimum and maximum values for each of the dimensions shown in the following table. (table I).

The highest score corresponds to nobility (2.78) and fixed attention (2.69) and the lowest to increasing fighting spirit (1.84).

We have compared the results obtained in Madrid with those obtained in El Puerto de Santa Maria for the years 2004, 2005 and 2006 (assessed with the Student-t test, $\mathrm{p}<0.05)$ (table II).

Correlation between the EBL-10 variables

To try to evaluate the statistical relationship between the EBL 10 variables we proceeded in the first place to calculate the correlation matrix between them. For this, all the measurements carried out in all the evaluated animals were used. The correlation analysis was done using Pearson's lineal correlation coefficient. The results are shown in table III.

From the previous data matrix we can obtain valuable information about the relationship between the different variables, of which the most relevant are indicated here: Thus, we can see how mobility correlates in an important and significant way with quick to start charge $(r=0.838)$, with transmission $(\mathrm{r}=0.739)$ and increased fighting spirit $(\mathrm{r}=0.712)$ quick to start charge strongly correlates with transmission $(\mathrm{r}=$ 0.750 ) and fixed attention with charging at the cape with style $(r=0.643)$. We can also observe how charging at the picador's horse does not show any strong correlations with any other variable. On the other hand, charging at the cape with style, correlates fundamentally with the aforementioned fixed attention, with quick to start charge $(\mathrm{r}=$ $0.647)$ and with nobility $(r=0.582)$. Fierceness, as expected, correlates negatively with nobility ( $\mathrm{r}=-0.175$ ) but relates positively and strongly with transmission $(\mathrm{r}=0.760)$, mobility $(\mathrm{r}=0.671)$, increased fighting spirit $(\mathrm{r}=0.670)$ and strength $(\mathrm{r}=0.653)$. The nobility variable has its greatest correlation, as mentioned before, with charging at the cape with style. There is a slight negative correlation between nobility and strength $(\mathrm{r}=-0.175)$.

\section{The creation of synthetic variables through ACP}

To continue we carried out the ACP, selecting the first two eigenvalues greater than one, knowing $11=5.453$ which explains $54.53 \%$ of the initial variability and $12=1.861$ 
Table II. Differences between means evaluated in bulls fought in Madrid (San Isidro 2004,2005,2006) and El Puerto de Santa María (years 2004, 2005, 2006). (Diferencias de las medias evaluadas en los toros lidiados en Madrid (San Isidro, 2004, 2005, 2006) y El Puerto de Santa María (años 2004, 2005, 2006)).

\begin{tabular}{|c|c|c|c|c|c|}
\hline Dimensions & Bullring & $\mathrm{n}$ & Mean & SD & $\mathrm{P}$ \\
\hline \multirow[t]{2}{*}{ Lack of mobility-mobility } & Madrid & 262 & 2.73 & 0.766 & \\
\hline & Puerto & 118 & 2.27 & 0.834 & 0.000 \\
\hline \multirow[t]{2}{*}{ Indecision-decisive, quick to start charge } & Madrid & 262 & 2.49 & 0.811 & \\
\hline & Puerto & 118 & 2.23 & 0.919 & 0.005 \\
\hline \multirow[t]{2}{*}{ Distraction-fixed attention } & Madrid & 262 & 2.78 & 0.696 & \\
\hline & Puerto & 118 & 2.49 & 0.875 & 0.002 \\
\hline \multirow[t]{2}{*}{ Charging at picador's horse without style-with style } & Madrid & 261 & 2.02 & 0.759 & \\
\hline & Puerto & 118 & 1.68 & 0.905 & 0.001 \\
\hline \multirow[t]{2}{*}{ Charging at lures without style-with style } & Madrid & 262 & 2.22 & 0.885 & \\
\hline & Puerto & 118 & 1.92 & 1.083 & 0.009 \\
\hline \multirow[t]{2}{*}{ Docility-fierceness } & Madrid & 262 & 2.59 & 0.861 & \\
\hline & Puerto & 118 & 2.36 & 0.688 & 0.006 \\
\hline \multirow[t]{2}{*}{ Cunningness-nobility } & Madrid & 262 & 2.82 & 0.898 & \\
\hline & Puerto & 118 & 2.69 & 0.832 & 0.198 \\
\hline \multirow[t]{2}{*}{ Weakness-strength } & Madrid & 262 & 2.53 & 1.012 & \\
\hline & Puerto & 118 & 2.47 & 0.844 & 0.575 \\
\hline \multirow[t]{2}{*}{ Lack of transmission to public-transmission } & Madrid & 262 & 2.16 & 1.133 & \\
\hline & Puerto & 118 & 1.95 & 0.959 & 0.062 \\
\hline \multirow[t]{2}{*}{ Decreasing fighting spirit-increasing fighting spirit } & Madrid & 262 & 1.95 & 1.022 & \\
\hline & Puerto & 118 & 1.61 & 1.046 & 0.003 \\
\hline
\end{tabular}

Comparison of the means was performed with the T-Student test.

which explains $18.615 \%$, together explaining almost $73.15 \%$ of the initial variance. This is sufficient criteria to enable the selection of the first two associated components (Y1, Y2)(tableIV).

To understand the meaning of both components it is necessary to study the correlation between the variables originally measured and the selected components, which facilitates the interpretation of the new synthetic variable generated.

The correlation of the variable components matrix (table V), shows us that the greatest correlation of the first component goes with the quick to charge variable $(r=$ 0.903 ), followed by those obtained with increasing fighting spirit $(\mathrm{r}=0.882)$, mobility $(\mathrm{r}=0.881)$, and transmission $(\mathrm{r}=0.881)$. Also, we can see an important correlation with fierceness $(r=0.779)$. The variable with least weight in this component is nobility $(r=$ 0.188).

The greatest correlation with the second component is obtained with the nobility variable $(\mathrm{r}=0.879)$, followed by those obtained with fixed attention $(\mathrm{r}=0.570)$ and then by charging at the cape with style ( $\mathrm{r}=$ 0.551 ). In opposition (variables with negative influence), are increasing fighting spirit, transmission, fierceness and strength. We can associate this component with the manageability.

We have finally named the two new synthetically generated variables: aggresiveness (casta), and manageability (toreabilidad), which are defined in the following way:

Aggresiveness $=0.386$ quick to start 
ASSESSMENT SCALE FOR BEHAVIOUR IN BULFIGHTING CATTLE (EBL 10)

Table III. Correlation matrix of the EBL 10 dimensions. (Matriz de correlaciones de las dimensiones de EBL 10).

\begin{tabular}{|c|c|c|c|c|c|c|c|c|c|}
\hline & 2 & 3 & 4 & 5 & 6 & 7 & 8 & 9 & 10 \\
\hline \multirow[t]{2}{*}{1} & $0.838^{* *}$ & $0.523^{* *}$ & $0.414^{* *}$ & $0.574^{\star *}$ & $0.671^{* *}$ & 0.099 & $0.562^{\star *}$ & $0.739^{* *}$ & $0.712^{\star *}$ \\
\hline & 0.000 & 0.000 & 0.000 & 0.000 & 0.000 & 0.054 & 0.000 & 0.000 & 0.000 \\
\hline \multirow[t]{2}{*}{2} & 1 & $0.560^{* *}$ & $0.415^{\star *}$ & $0.647^{* *}$ & $0.661^{* *}$ & $0.159^{* *}$ & $0.559^{* *}$ & $0.750^{* *}$ & $0.747^{* *}$ \\
\hline & - & 0.000 & 0.000 & 0.000 & 0.000 & 0.002 & 0.000 & 0.000 & 0.000 \\
\hline \multirow[t]{2}{*}{3} & & 1 & $0.296^{\star *}$ & $0.643^{* *}$ & $0.299^{* *}$ & $0.510^{* *}$ & $0.136^{\star *}$ & $0.393^{* *}$ & $0.506^{* *}$ \\
\hline & & - & 0.000 & 0.000 & 0.000 & 0.000 & 0.008 & 0.000 & 0.000 \\
\hline \multirow[t]{2}{*}{4} & & & 1 & $0.349^{* *}$ & $0.424^{\star *}$ & 0.057 & $0.299^{* *}$ & $0.392^{* *}$ & $0.429^{* *}$ \\
\hline & & & - & 0.000 & 0.000 & 0.269 & 0.000 & 0.000 & 0.000 \\
\hline \multirow[t]{2}{*}{5} & & & & 1 & $0.305^{\star *}$ & $0.570^{* *}$ & $0.240^{* *}$ & $0.503^{\star *}$ & $0.582^{\star *}$ \\
\hline & & & & - & 0.000 & 0.000 & 0.000 & 0.000 & 0.000 \\
\hline \multirow[t]{2}{*}{6} & & & & & 1 & $-0.175^{\star *}$ & $0.653^{* *}$ & $0.760^{* *}$ & $0.670^{* *}$ \\
\hline & & & & & - & 0.001 & 0.000 & 0.000 & 0.000 \\
\hline \multirow[t]{2}{*}{7} & & & & & & 1 & $-0.163^{* *}$ & -0.031 & $0.148^{* *}$ \\
\hline & & & & & & - & 0.001 & .0550 & 0.004 \\
\hline \multirow[t]{2}{*}{8} & & & & & & & 1 & $0.701^{* *}$ & $0.581^{* *}$ \\
\hline & & & & & & & - & 0.000 & 0.000 \\
\hline \multirow[t]{2}{*}{9} & & & & & & & & 1 & $0.808^{\text {** }}$ \\
\hline & & & & & & & & - & 0.000 \\
\hline
\end{tabular}

1: Mobility; 2: Quick to start charge; 3: Fixed attention; 4: Charge at picador's horse; 5 : Charge at lures; 6: Fierceness; 7: Nobility; 8: Strength; 9: Transmission; 10: Increased fighting spirit. ${ }^{* *} p<0.05$.

charge +0.377 increasing braveness +0.377 mobility +0.377 transmission +0.335 fierceness $+0.302+$ charging at lures with style +0.219 strength +0.268 fixed attention
+0.234 charging at picador's horse with style +0.080 nobility.

Manageability $=0.644$ nobility +0.417 fixed attention +0.403 charging at lures with

Table IV. Component selection. Distribution of eigenvalues and percentages of explained variability. (Selección de componentes. Distribución de autovalores y porcentaje de variabilidad explicada).

\begin{tabular}{cccc}
\hline Components & Eigenvalues & \% of the initial variability & Accumulated percentage \\
\hline 1 & 5.453 & 54.532 & 54.532 \\
2 & 1.861 & 18.615 & 73.147 \\
3 & 0.752 & 7.520 & 80.667 \\
4 & 0.472 & 4.719 & 85.386 \\
5 & 0.355 & 3.546 & 88.932 \\
6 & 0.321 & 3.213 & 92.145 \\
7 & 0.260 & 2.596 & 94.741 \\
8 & 0.222 & 2.224 & 96.966 \\
9 & 0.160 & 1.596 & 98.562 \\
10 & 0.144 & 1.438 & 100.000 \\
\hline
\end{tabular}

Archivos de zootecnia vol. 60, núm. 230, p. 221. 


\section{ALMENARA-BARRIOSY GARCÍA GONZÁLEZ-GORDON}

Table $\boldsymbol{V}$. Correlation matrix of the variables and the selected principal components. (Matriz de correlaciones entre las variables y las componentes seleccionadas).

\begin{tabular}{lcc}
\hline & \multicolumn{2}{c}{ Components } \\
Dimensions & Y1 & -0.038 \\
\hline Lack of mobility-mobility & 0.881 & 0.029 \\
Indecision-decisive, quick to start charge & 0.903 & 0.570 \\
Distraction-fixed attention & 0.628 & -0.024 \\
Charging at picador's horse without style-with style & 0.549 & 0.551 \\
Charging at lures without style-with style & 0.707 & -0.411 \\
Docility-fierceness & 0.784 & 0.879 \\
Cunningness-nobility & 0.188 & -0.475 \\
Weakness-strength & 0.680 & -0.248 \\
Lack of transmission to public-transmission & 0.881 & -0.033 \\
Decreasing fighting spirit-increasing fighting spirit & 0.882 & \\
\hline
\end{tabular}

style +0.021 quick to start charge -0.017 charge at picador's horse with style -0.024 increasing braveness -0.028 mobility -0.182 transmission -0.301 fierceness -0.347 strength.

\section{DISCUSSION}

A scale has been designed to measure behaviours in fighting cattle. The viability criteria (applicability, acceptability and practicality), are adequate. We believe that the constructed scale complies with the reliability between evaluators criteria that are advocated for this type of instrument, with high reliability indexes expressed in the results.

The validity study of the scale has allowed the appropriate analysis of the correlation between the variables that make it up, allowing the comparison of results. With the PCA we have created two synthetic variables as functions of a set of intermediate variables, each one of which contributes to quantify some aspect or feature of the concept of bravery (Silva 1997). Both variables, we can say, are valid. In other words, they have the capacity to really measure the concept intended for measurement. Both variables present face validity that relates to the fact that the synthetic variables measure what it is wanted. The content validity, measured by experts' consensus, relates to the capacity that the synthetic variable components cover the spectrum of the concept to be defined (Silva, 1997), (Dowell and Newell, 1987). In this study, the experts consulted from The Union of Brave Bull Breeders, U.C.T.L. (breeders, veterinary surgeons), professionals and enthusiasts who are learned about these subjects, have seen all the elements which intuitively correspond with the ideas of aggressiveness and manageability, present in both synthetic variables.

This study will enable new ways to develop the difficult process of understanding the behaviour associated with bravery, and therefore with breeding selection. Finally, our ultimate goal is to provide objective data and measurements to help breeders to make the right decisions.

\section{CONCLUSION}

For the first time, it has been able to take measurements in a reliable and valid way, during a bullfight, of the variables associated with brave behaviour. It has been possible to analyse the information obtained statistically and the results are acceptable for breeders' and professionals' interests. 


\section{ACKNOWLEDGEMENTS}

It is evident that all research is brought to light by a series of motivations. In no uncertain terms, the brave bull ranch of Don Manuel Pío García Fernández- Palacios has been at the forefront of this work. He has been our driving force and his plaza de tientas (bravery testing bullring), has been our laboratory. From here, we would like to offer him our thanks. We would also like to thank Diana Thurston, from the London Taurine Club, for the specially difficult

\section{REFERENCES}

Aguilar, I.1991. Predicción de la bravura y comportamiento en campo del toro de Lidia. Taurología. Revista Cultural Taurina, 6: 77-82.

Almenara, J., González, J.L., García, C. y Peña, P. 1998. ¿Qué es el análisis de componentes principales?. Sección Notas de Metodología y Estadística. Jano, 55: 18-24.

Almenara, J. y García, R. 2004. Evaluación de la bravura de los toros lidiados en la feria de San Isidro 2004, mediante la escala EBL-10. Tercio de Varas, El Puerto de Santa María. 12: 19-21.

Almenara, J. y García, R., 2005. Una valoración científica de la bravura del toro: estudio de los toros lidiados en San Isidro (Madrid 2004-2005). Publicación del Servicio de Actividades Culturales del Aula de Tauromaquia. Universidad San Pablo-CEU. Madrid. Curso 2005-2006.

Cuadras, C.M. 1996. Métodos de análisis multivariante. Eunibar S.A. Barcelona.

Domínguez, J. 2005. Los toros de Lidia en la economía. Rev. Inst. Estudios Económicos. Número dedicado a: Economía de la Ganadería de Lidia en España, 3: 83-98.

Dowell, I. and Newell, C.1987. Measuring Health. Oxford University Press. New York.

García, R., Almenara, J., Valdés, J., Navarro, J.I., Salvador, L. y Fernández, R. 2002. Evaluación estandarizada de la bravura I. Disponible en: Toroslidia.com. Revista electrónica de la Unión de Criadores de Toros de Lidia. (15/01/09).

García, R., Almenara, J., Valdés, J., Navarro, J.I., Salvador, L. y Fernández, R. 2003. Evaluación estandarizada de la bravura II. Disponible en:
English translation of this paper.

Equally we would like to thank all the different people, who from numerous forums have invited us to share our ideas in analysing the bravery of fighting bulls: The University of Navarra Debating Group, The University of Cadiz taurine Debating Group, The U.C.T.L., The Hotel Monasterio Discussion Group, The Jerez Casino, and lastly, The Tauromaquia Debating Group of San Pablo University, Madrid, who published preliminary aspects of this work, (Almenara and García 2005).

Toroslidia.com. Revista electrónica de la Unión de Criadores de Toros de Lidia. (15/01/09).

García, R. y Almenara, J. 2004. Escala de evaluación de la bravura para bovinos de Lidia (EBL10). Revista de Estudios Taurinos. Fundación de Estudios taurinos. Sevilla. 18: 251-278.

García, R. and Almenara, J. 2005. Behaviour assessment in fighting bovines. European Congress of Psychology. Granada.

González, B. 1991. Análisis multivariante. Aplicación al ámbito sanitario. SE Editores, S.A. Barcelona.

Hotelling, H. 1933. Analysis of a complex of statistical variables into principal components. J. Educ. Psychol., 24: 417-441.

Jolliffe, I.T. 2002. Principal component analysis. Springer-Verlag. New York.

Pearson, K. 1901. On lines and planes of closest fit to systems of points in space. Philos. Mag., 6: 559-572.

Salvador, L., Romero, C. y González-Saiz, F. 2000. Guías para la descripción y selección de instrumentos de evaluación en Psiquiatría. En: Balbuena, A. Berrios, G.E. Fernández de Larrinoa, P. (Eds.). Medición Clínica en Psiquiatría y Psicología. Masson-Salvat. Barcelona.

Schuling, J., De Haaen, R., Limburg, M. and Groenier, K.H. 1993. The frenchay activities index; assessment of functional status in stroke patients. Strokes, 24: 1173-1177.

Silva, L.C. 1997. Cultura estadística e investigación científica en el campo de la salud: una mirada crítica. Díaz de Santos. Madrid. 


\section{ALMENARA-BARRIOSY GARCÍA GONZÁLEZ-GORDON}

Silva, B., Gonzalo, A. and Cañón, J. 2006. Genetic parameters of aggressiveness, ferocity and mobility in the Fighting Bull breed. Anim. Res., 55: 65-70

UCTL.1996. Programa de mejora genética, selección conservación de la Unión de Criadores de
Toros de Lidia. Disponible en: Toroslidia.com. Revista electrónica de la Unión de Criadores de Toros de Lidia. (15/01/09).

Vallejo, M., Gonzalo, A. y Cañón, J. 2001. Relaciones entre los caracteres de comportamiento del toro de Lidia. Toro Bravo, 28: 29-33.

Archivos de zootecnia vol. 60, núm. 230, p. 224. 